\title{
Synthesis, photophysical and nonlinear optical properties of $[1,2,5]$ oxadiazolo[3,4-b]pyrazine-based linear push-pull systems
}

\author{
Egor V. Verbitskiy ${ }^{\mathrm{a}, \mathrm{b}, *}$, Sylvain Achelle ${ }^{\mathrm{c}, *}$, Filip Bureš ${ }^{\mathrm{d}, *}$, Pascal le Poul $^{\mathrm{c}}$, Alberto Barsella ${ }^{\mathrm{e}}$, \\ Yuriy A. Kvashnin ${ }^{\text {a }}$, Gennady L. Rusinov ${ }^{\mathrm{a}, \mathrm{b}}$, Françoise Robin-le Guen ${ }^{\mathrm{c}}$, Oleg N. Chupakhin ${ }^{\mathrm{a}, \mathrm{b}}$, \\ Valery N. Charushin ${ }^{a, b}$ \\ ${ }^{a}$ I. Postovsky Institute of Organic Synthesis, Ural Branch of the Russian Academy of Sciences, S. Kovalevskaya Str., 22, Ekaterinburg, 620108, Russia \\ ${ }^{\mathrm{b}}$ Ural Federal University, Mira St. 19, Ekaterinburg, 620002, Russia

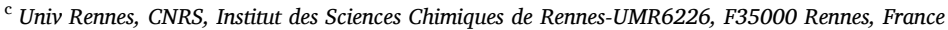 \\ ${ }^{\mathrm{d}}$ Institute of Organic Chemistry and Technology, Faculty of Chemical Technology, University of Pardubice, Studenská 573, Pardubice 53210, Czech Republic \\ ${ }^{\text {e }}$ Département d'Optique ultrarapide et Nanophotonique, IPCMS, UMR CNRS 7504, Université de Strasbourg, 23 rue du Loess, BP 43, 67034 Strasbourg Cedex 2, France
}

\section{A R T I C L E I N F O}

\section{Keywords:}

nitrogen heterocycles

donor-acceptor systems

nonlinear optic

fluorescence

intramolecular charge transfer

\begin{abstract}
A B S T R A C T
A series of D- $\pi$-A chromophores based on $[1,2,5]$ oxadiazolo[3,4- $b]$ pyrazine electron-withdrawing group has been designed. The influence of the $\pi$-conjugated linker (1,4-phenylene and 2,5-thienylene) and the amino-electrondonating group (diphenylamino and carbazol-9-yl) was studied by cyclic voltammetry, UV-Vis and emission spectroscopy. The second order nonlinear optical properties were also studied using the electric field induced second harmonic generation (EFISH) method. The experimental results have been rationalized by theoretical DFT calculations.
\end{abstract}

\section{Introduction}

Organic nonlinear optical (NLO) materials have attracted considerable attention in recent years because of their potential applications in various fields of optoelectronics and photonics, including optical communications, optoelectronic transfer, optical signal process and optical data storage [1]. The main advantages of these materials are high NLO coefficients, ultrafast optical responses, flexible molecular design and synthesis and higher optical damage threshold, as compared to traditional inorganic solids. Generally, the NLO properties of organic materials are dependent on the molecular structures of chromophores. Typically, in order to show a significant second-order NLO response, a molecule must be non-centrosymmetric, with intramolecular charge transfer (ICT) transitions at relatively low energy and characterized by a large transition dipole moment and a large difference between the excited state and the ground state molecular dipole moment [1e]. This can be achieved in linear organic molecules by connecting an electron-donor and an electron-acceptor group through a $\pi$-conjugated polarizable spacer, as it occurs in classical organic dipolar push-pull systems [2].

Pyrazine is a nitrogen based heterocyclic compound with a rigid planar conjugated structure. Due to the electron-deficient character of the pyrazine, the pyrazinyl fragment can be used as electronwithdrawing group in push-pull structures. The incorporation of pyrazine units in luminescent materials has been recently reviewed [3]. Moreover, it has been shown that push-pull pyrazine derivatives exhibit interesting second-order (frequency doubling) [4] and third-order (two photon absorption) [5] NLO properties.

It has been demonstrated that $[1,2,5]$ oxadiazolo[3,4-b]pyrazine (furazanopyrazine) exhibits higher electron-withdrawing character than similar non-annulated pyrazine analogues [6]. Recently, the $[1,2,5]$ oxadiazolo[3,4-b]pyrazine core has been used as an acceptor part of push-pull molecules exhibiting pronounced fluorescence in the solid state and sensitivity towards nitroaromatic compounds [7].

This work represents further extension of our previous research focusing on the design of novel fluorophores that incorporate diazine scaffold. In this contribution we describe the synthesis of a new series of D- $\pi-A$ [where A equals to the 1,2,5-oxadiazolo[3,4-b]pyrazine acceptor, $D$ represents triphenylamine or carbazole donors, and $\pi$ involves thienylene or phenylene groups] push-pull chromophores $\mathbf{7 a , b}$ and $\mathbf{8 a} \mathbf{a} \mathbf{b}$ and systematic investigation of their photophysical and second order NLO properties. The influences of the type of the $\pi$ - linker as well as the

\footnotetext{
* Corresponding author.

E-mail address: sylvain.achelle@univ-rennes1.fr (S. Achelle).
} 
nature of the electron-donating group on the photophysical properties were thoroughly studied and structure-property relationships were elucidated.

\section{Results and Discussion}

\subsection{Synthesis}

The synthesis of the linear push-pull systems required 5-(4-bromophenyl)-[1,2,5]oxadiazolo[3,4-b]pyrazine (3) and 5-(5-bromothiophen2 -yl)-[1,2,5]oxadiazolo[3,4-b]pyrazine (5) as starting materials. Compound 3 was prepared via a two-step procedure from commercially available 4'-bromoacetophenone (1) in 73\% overall yield (Scheme 1).

The second starting material (5) was obtained by bromination of previously described 5-(1-benzothiophen-3-yl)pyrimidine (4) [7] with an excess of $N$-bromosuccinimide in $85 \%$ yield (Scheme 2).

The target chromophores $\mathbf{7 a - b}$ and $\mathbf{8 a - b}$ were synthesized in high yields through the Suzuki-Miyaura cross-coupling reactions shown in Schemes 3 and 4 . Furazanopyrazines $\mathbf{3}$ and $\mathbf{5}$ were coupled with the corresponding pinacol esters of 4-(diphenylamino)phenylboronic (6a) and $9 H$-carbazole-9-(4-phenyl)boronic (6b) acids under reflux in 1,4dioxane by using $\mathrm{Pd}\left(\mathrm{PPh}_{3}\right)_{4}$ as catalyst. These reactions afforded the corresponding D- $\boldsymbol{\pi}$-A dyes 7a-d and 8a-d in good yields (Schemes 3 and 4).

\subsection{Electrochemical properties}

Electrochemical behavior of compounds 7 and $\mathbf{8}$ was studied by cyclic voltammetry (CV) in $\mathrm{CH}_{2} \mathrm{Cl}_{2}$ containing $\mathrm{Bu}_{4} \mathrm{NPF}_{6}$ electrolyte at a scan rate of $0.1 \mathrm{~V} / \mathrm{s}$. The working electrode was a glassy carbon disk, $\mathrm{Pt}$ wire was used as the counter electrode and an $\mathrm{Ag}$ wire as a reference electrode. Ferrocene was used as an internal reference for potential measurements. The first oxidation/reduction peak potentials and their differences are listed in Table 1 and CV diagrams are shown in Fig. 1.

Compounds $\mathbf{7 b}$ and $\mathbf{8 b}$ bearing the carbazole moiety as an electrondonating group exhibit a first irreversible oxidation process at 0.95 and $0.96 \mathrm{~V} v s$. ferrocene. When the donor is the diphenylamino moiety, the first oxidation is reversible and measured $E_{1 / 2}$ are much lower $(0.55 \mathrm{~V}$ for $7 \mathbf{a}$ and $0.57 \mathrm{~V}$ for $\mathbf{8 a}$; see Fig. 1) in accordance with the stronger electron-donating effect of the diphenylamino group. For these two compounds, a second irreversible oxidation peak can be observed at the higher potential that modifies the reversibility of the first system, on the reverse scan.

All compounds bear the same oxadiazolopyrazine electronwithdrawing group. For this reason, the same behavior can be observed on reduction when scanning from 0 to $-2 \mathrm{~V}$. All compounds show a first reversible reduction around $-1.1 \mathrm{~V} v s$. Fc and a second quasireversible system around $-2 \mathrm{~V}(\mathrm{scan}$ rate $=0.1 \mathrm{~V} / \mathrm{s})$. The latter becomes reversible when the scanning rate is increased to $1 \mathrm{~V} / \mathrm{s}$ (Fig. S25). The obtained half-wave potentials for both systems are similar regardless of the nature of the electron-donating moieties and of the $\pi$-conjugated linker. This trend indicates a weak interaction between the donor and the acceptor.

The HOMO/LUMO energies were calculated from potential values (the first oxidation and reduction processes) to evaluate the electrochemical band gap. The $E_{\mathrm{LUMO}}$ remains unaltered as all chromophores showed the same reduction behavior. On the other hand, the $E_{\text {HOMO }}$ of diphenylamino derivatives is higher leading to a decreased band gap for compounds $7 \mathbf{a}$ and $8 \mathbf{a}$. These results correspond to the evolution of $\lambda_{\max }$ values obtained from the electronic spectra.

\subsection{Photophysical properties}

The photophysical properties of compounds 7 and 8 have been studied in various aprotic solvents of increasing polarity and the results are summarized in Table 2. All compounds are emissive in $n$-heptane. Carbazole derivatives $\mathbf{7 b}$ and $\mathbf{8 b}$ are also emissive in 1,4-dioxane but no emission is observed in solvents of higher polarity. For push-pull derivatives, such observation is rationalized by decreased emission intensity observed in polar solvents due to lowered energies of the ICT excited state [8]. Fig. 2 shows the normalized absorption and emission spectra in $n$-heptane. As expected, the replacement of the 1,4-phenylene linker (compounds 7) by a 2,5-thienylene one (compounds 8) induces a red shift of both absorption and emission bands as well as increases the molar extinction coefficient due to a better charge transfer through the heterocycle [9]. Similarly to previous observation [10], the diphenylamino derivatives exhibited red-shifted absorption and emission. This effect is more pronounced than changing the $\pi$-conjugated linker. The absorption and emission maxima increase in the following order $\mathbf{7 b}<$ $\mathbf{8 b}<\mathbf{7 a}<\mathbf{8 a}$. Compound $\mathbf{8 b}$ exhibited the highest emission quantum yield in $n$-heptane $\left(\Phi_{\mathrm{F}}=0.96\right)$. The lowest value was observed for compound $7 \mathbf{b}\left(\Phi_{\mathrm{F}}=0.06\right)$, but this compound exhibited much higher quantum yield in 1,4-dioxane $\left(\Phi_{\mathrm{F}}=0.29\right)$. Fig. 3 shows the color of $n$-heptane solutions of compounds 7-8 under UV-irradiation.

Whereas only moderate absorption solvatochromism was observed for $\mathbf{7}$ and $\mathbf{8}$, which does not seem to be correlated to the solvent polarity (the most red-shifted absorption bands are observed in $\mathrm{CH}_{2} \mathrm{Cl}_{2}$ ), a strong positive emission solvatochromism was observed for carbazole derivatives $\mathbf{7 b}$ and $\mathbf{8 b}$ as illustrated in Figs. 4 and 5. It should be noted that emission solvatochromism was not observed for diphenylamino derivatives since the emission is fully quenched in solvents of higher polarity than $n$-heptane. This phenomenon, which is due to stabilization of the highly-polar emitting state by polar solvent, has been extensively described for push-pull derivatives [11]. It should be noted however that the quantum yield of compound $\mathbf{7 b}$ is higher in 1,4-dioxane than in $n$-heptane, probably due to aggregation in this latter solvent. The slope of the regression line of the emission maxima plotted versus the Dimroth-Reichardt polarity parameter $\left(\mathrm{E}_{\mathrm{T}}(30)\right)$ is a way to evaluate the ICT [12]. The slope observed for compounds $\mathbf{7 b}$ and $\mathbf{8 b}$ (see Fig. S1 in ESI) are similar or higher as compared to pyrazine push-pull derivatives with diphenylamino substituents and more extended $\pi$-conjugated linker [13], indicating that the oxadiazolo part significantly enhances the electron-withdrawing character of the pyrazine.

\subsection{Second order nonlinear optical properties}

The second order NLO properties have been studied in chloroform solution by the electric-field induced second harmonic generation (EFISH) method at a non-resonant incident wavelength of $1907 \mathrm{~nm}$. The second harmonic at $\lambda=953 \mathrm{~nm}$ is therefore well clear of the absorption bands of the chromophores. This method provides the NLO response as the scalar product between the permanent dipolar moment of the

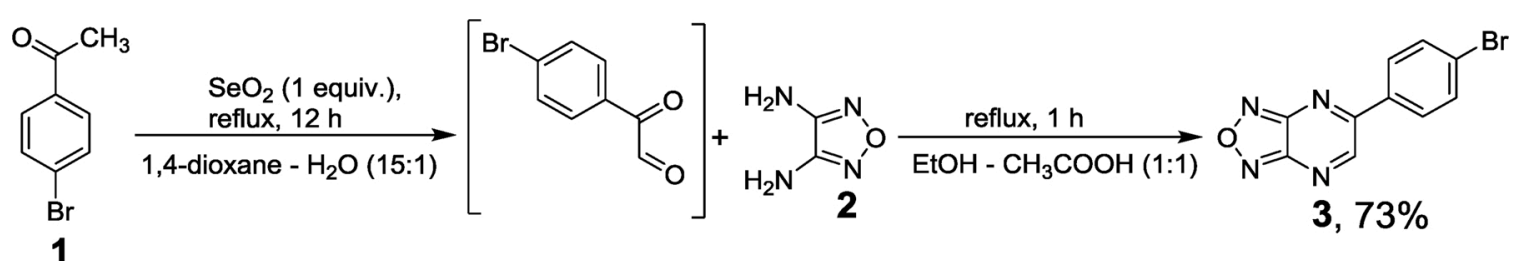

Scheme 1. Synthesis of 5-(4-bromophenyl)-[,2,5] oxadiazolo[3,4-b]pyrazine (3). 
<smiles>CC(C)c1cc(-c2cccs2)nc2nonc12</smiles>

Scheme 2. Synthesis of 5-(5-bromothiophen-2-yl)-[1,2,5]oxadiazolo[3,4-b]pyrazine (5).<smiles>Brc1ccc(-c2cnc3nonc3n2)cc1</smiles>

3<smiles>CC1(C)OB([Al])OC1(C)C</smiles>

$6 a, b$
$\mathrm{Pd}\left(\mathrm{PPh}_{3}\right)_{4}(10 \mathrm{~mol} \%)$, $\mathrm{K}_{3} \mathrm{PO}_{4}$ (2.5 equiv.), $15 \mathrm{~h}$, reflux

1,4-dioxane<smiles>COn1nc2ncc(-c3ccc(Br)cc3)nc2n1</smiles>

7 a, $85 \%$

$7 \mathrm{~b}, 77 \%$

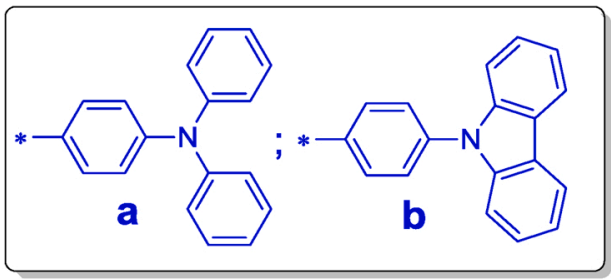

Scheme 3. Synthesis of 5-[4-(heteroaryl)phenyl]-[1,2,5]oxadiazolo[3,4-b]pyrazines (7a,b).

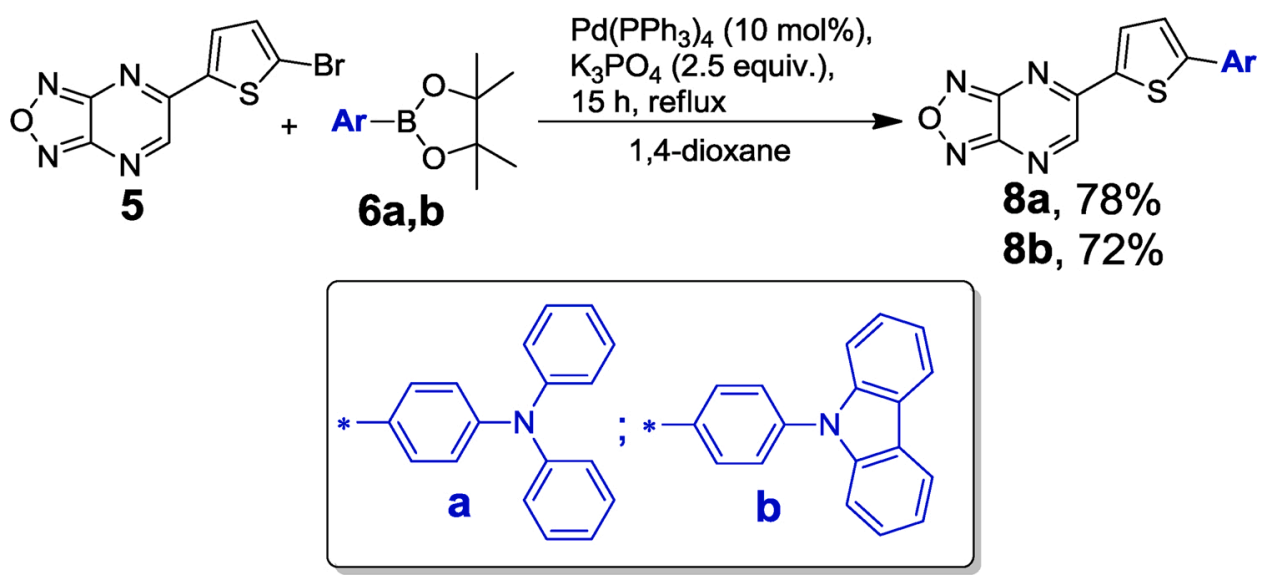

Scheme 4. Synthesis of 5-[5-(heteroaryl)thiophen-2-yl]-[1,2,5] oxadiazolo[3,4-b]pyrazines (8a,b).

Table 1

Electrochemical data of compounds.

\begin{tabular}{lllllll}
\hline Comp. & $\begin{array}{l}E_{1 / 2}^{\text {ox1 }} \\
{[\mathrm{V}]^{\mathrm{a}}}\end{array}$ & $\begin{array}{l}E_{1 / 2}^{\mathrm{red} 1} \\
{[\mathrm{~V}]^{\mathrm{a}}}\end{array}$ & $\begin{array}{l}\Delta E \\
{[\mathrm{~V}]^{\mathrm{b}}}\end{array}$ & $\begin{array}{l}E_{\mathrm{HOMO}} \\
{[\mathrm{eV}]^{\mathrm{c}}}\end{array}$ & $\begin{array}{l}E_{\mathrm{LUMO}} \\
{[\mathrm{eV}]^{\mathrm{c}}}\end{array}$ & $\begin{array}{l}\lambda_{\max } \\
{[\mathrm{nm}]^{\mathrm{d}}}\end{array}$ \\
\hline 7a & 0.55 & -1.11 & 1.66 & -5.33 & -3.67 & 746 \\
7b & $0.95^{\mathrm{e}}$ & -1.10 & 2.05 & -5.73 & -3.69 & 604 \\
$\mathbf{8 a}$ & 0.57 & -1.14 & 1.71 & -5.35 & -3.64 & 727 \\
$\mathbf{8 b}$ & $0.96^{\mathrm{e}}$ & -1.09 & 2.05 & -5.74 & -3.69 & 606 \\
\hline
\end{tabular}

${ }^{\mathrm{a}}$ All potentials are given versus ferrocene.

b $\Delta E=E_{1 / 2}^{\text {ox1 }}-E_{1 / 2}^{\text {red1 }}$.

${ }^{\mathrm{c}} E_{\mathrm{HOMO} / \mathrm{LUMO}}=-\left(E^{\mathrm{ox} 1 / \mathrm{red} 1}+4.8\right)$.

d Calculated $\lambda_{\max }$ values $(\lambda=1241 / \Delta E)$.

${ }^{\mathrm{e}}$ Irreversible peaks Ep.

molecule $\vec{\mu}$ in fundamental state and the vector component of $\beta$ described as $\beta_{/ /}$[14]. The two level corrected $\mu \beta$ values $\left(\mu \beta_{0}\right)$ have been also calculated [15]. The results are presented in Table 3. It should be noted that positive $\mu \beta$ values are obtained indicating that both ground and excited states are polarized in the same direction and that the excited state is more polarized than ground state, in accordance with the emission solvatochromism observation (for $\mathbf{7 b}$ and $\mathbf{8 b}$ ). Compounds $\mathbf{8}$ exhibit higher NLO response than analogues 7 and the diphenylamino derivatives a show better $\mu \beta$ values than carbazole analogues $\mathbf{b}$. These results are coherent with the electrochemical and photophysical observations indicating better ICT for compounds possessing 2,5-thienylene linker and diphenylamino electron-donating group. The figure of merit of compound 8a appears particularly interesting.

\subsection{DFT calculations}

Spatial and electronic properties of compounds $\mathbf{7 a - b}$ and $\mathbf{8 a}-\mathbf{b}$ were investigated using Gaussian ${ }^{\circledR} 16 \mathrm{~W}$ software [17] package at the DFT level. Optimized geometries, energies of the frontier molecular orbitals, and ground state dipole moments $\mu$ and were calculated at DFT 

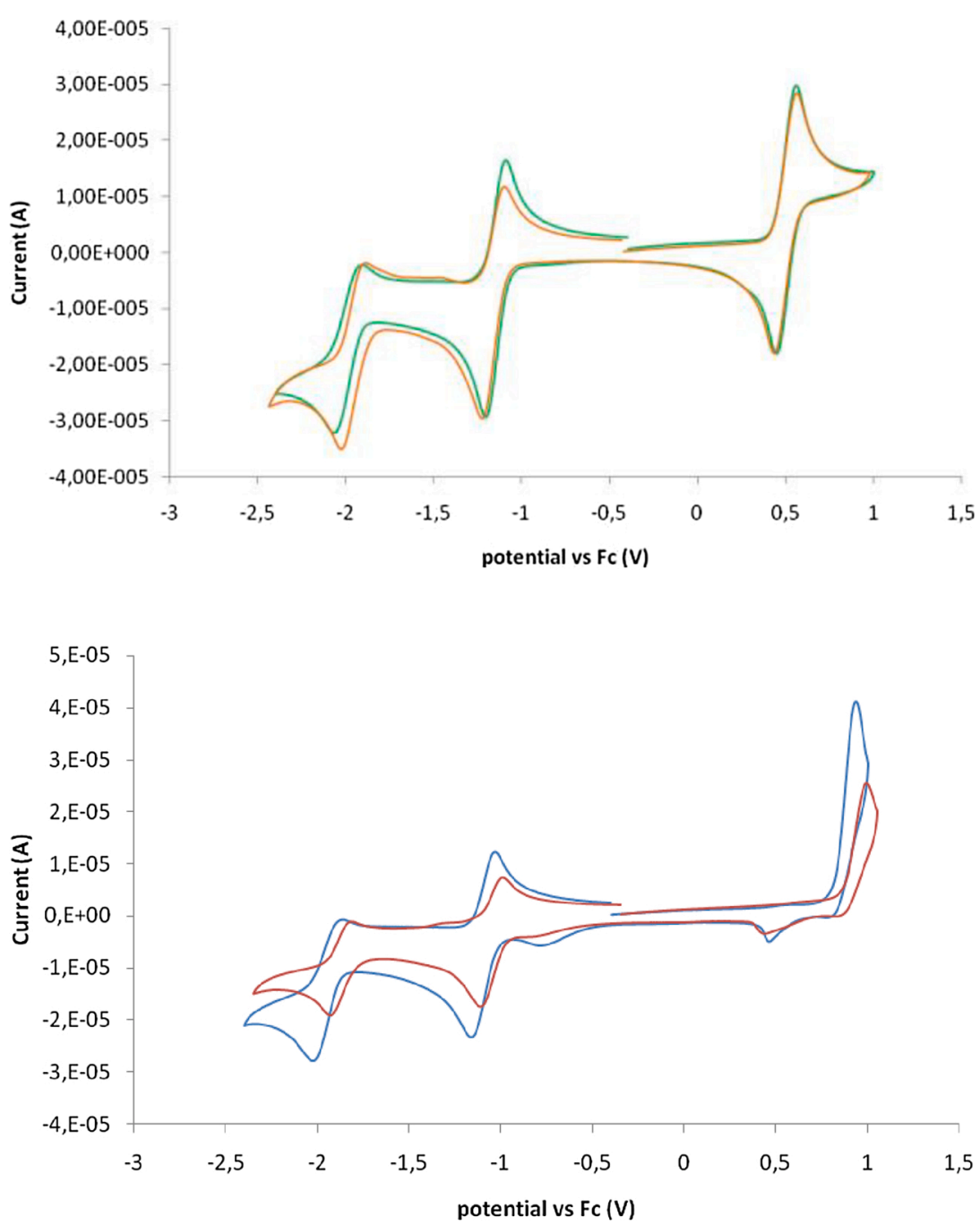

Fig. 1. Cyclic voltammograms of $7 \mathbf{a}$ (green), $\mathbf{8 a}$ (orange) $\mathbf{7 b}$ (blue) and $\mathbf{8 b}\left(\right.$ red) in $\mathrm{CH}_{2} \mathrm{Cl}_{2}$ solutions.

Table 2

UV/Vis and PL data in various solvents for compounds $\mathbf{7}$ and $\mathbf{8 .}$

\begin{tabular}{|c|c|c|c|c|c|}
\hline Compds & Solvent & $\begin{array}{l}\lambda_{\mathrm{abs}}(\varepsilon) \\
{[\mathrm{nm}]\left[\left(\mathrm{mM}^{-1} \mathrm{~cm}^{-}\right.\right.} \\
\left.\left.{ }^{1}\right]\right)\end{array}$ & $\begin{array}{l}\lambda_{\mathrm{em}} \\
{[\mathrm{nm}]}\end{array}$ & $\Phi_{\mathrm{F}}{ }^{\mathrm{a}}$ & $\begin{array}{l}\text { Stokes shift }\left[\mathrm{cm}^{-}\right. \\
\left.{ }^{1}\right]\end{array}$ \\
\hline \multirow{4}{*}{$7 a$} & $n$-heptane & $473(18.4)$ & 570 & 0.54 & 3598 \\
\hline & $\begin{array}{l}1,4- \\
\text { dioxane }\end{array}$ & 466 (12.4) & $-\mathrm{b}$ & $-b$ & $-b$ \\
\hline & $\mathrm{CH}_{2} \mathrm{Cl}_{2}$ & 485 (11.8) & $-\mathrm{b}$ & $-\mathrm{b}$ & $-b$ \\
\hline & $\mathrm{MeCN}$ & 457 (16.4) & $-\mathrm{b}$ & $-\mathrm{b}$ & $-\mathrm{b}$ \\
\hline \multirow{5}{*}{$7 b$} & $n$-heptane & 414 (12.3) & 521 & 0.06 & 4961 \\
\hline & $\begin{array}{l}1,4- \\
\text { dioxane }\end{array}$ & $401(8.7)$ & 619 & 0.29 & 8783 \\
\hline & $\mathrm{CH}_{2} \mathrm{Cl}_{2}$ & $403(8.9)$ & $-{ }_{-}^{b}$ & $-\mathrm{b}$ & $-b$ \\
\hline & $\mathrm{MeCN}$ & 389 (15.1) & $-\mathrm{b}$ & $-\mathrm{b}$ & $-\mathrm{b}$ \\
\hline & $n$-heptane & $514(33.2)$ & 607 & 0.39 & 2980 \\
\hline \multirow[t]{3}{*}{$8 a$} & $\begin{array}{l}1,4- \\
\text { dioxane }\end{array}$ & $511(22.7)$ & $-{ }^{b}$ & $-b$ & $-b$ \\
\hline & $\mathrm{CH}_{2} \mathrm{Cl}_{2}$ & 544 (22.7) & $-\mathrm{b}$ & $-b$ & $-b$ \\
\hline & $\mathrm{MeCN}$ & 518 (20.7) & $-\mathrm{b}$ & $-\mathrm{b}$ & $-\mathrm{b}$ \\
\hline \multirow{4}{*}{$8 b$} & $n$-heptane & $452(25.4)$ & 548 & 0.96 & 3875 \\
\hline & $\begin{array}{l}1,4- \\
\text { dioxane }\end{array}$ & $450(22.5)$ & 627 & 0.35 & 6273 \\
\hline & $\mathrm{CH}_{2} \mathrm{Cl}_{2}$ & $463(20.3)$ & $-b$ & $-b$ & $-b$ \\
\hline & $\mathrm{MeCN}$ & $447(22.6)$ & $-b$ & $-b$ & $-b$ \\
\hline
\end{tabular}

${ }^{\text {a }}$ Fluorescence quantum yield $( \pm 10 \%)$ determined relative to 9,10 -bis(phenylethynyl)antracene in cyclohexane $\left(\Phi_{\mathrm{F}}=1.00\right)$.

b No emission detected.

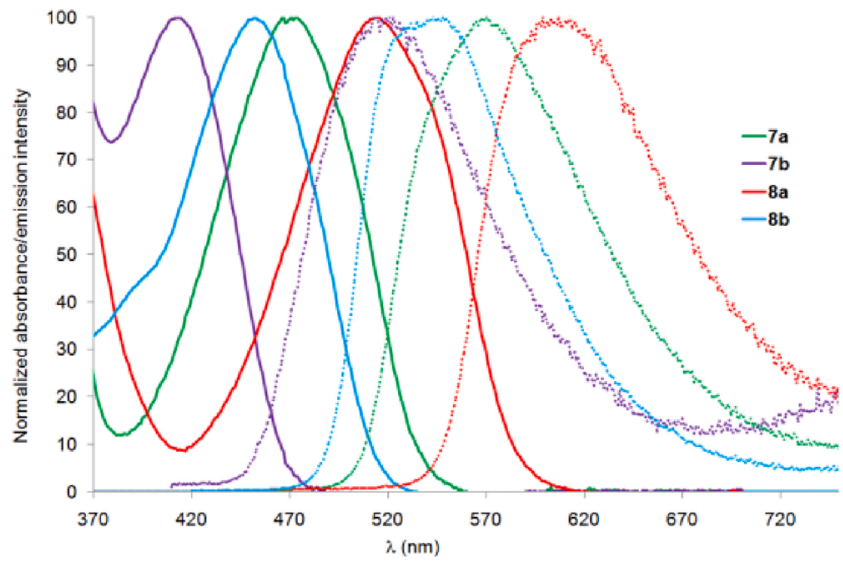

Fig. 2. Normalized UV/Vis (solid lines) and emission spectra (dashed lines) of compounds $\mathbf{7}$ and $\mathbf{8}$ in $n$-heptane.

B3LYP/6-311+G(2df,p) level in $\mathrm{CHCl}_{3}$ as shown in Table 4. The electronic absorption spectra and the first-order hyperpolarizabilities $\beta$ were calculated by TD-DFT method using CAM-B3LYP/6-311+G(2df,p) in $\mathrm{CHCl}_{3}$.

The calculated energies of the HOMO and the LUMO range from -5.83 to -5.45 and -3.61 and $-3.46 \mathrm{eV}$ (Fig. 6), respectively. Both 


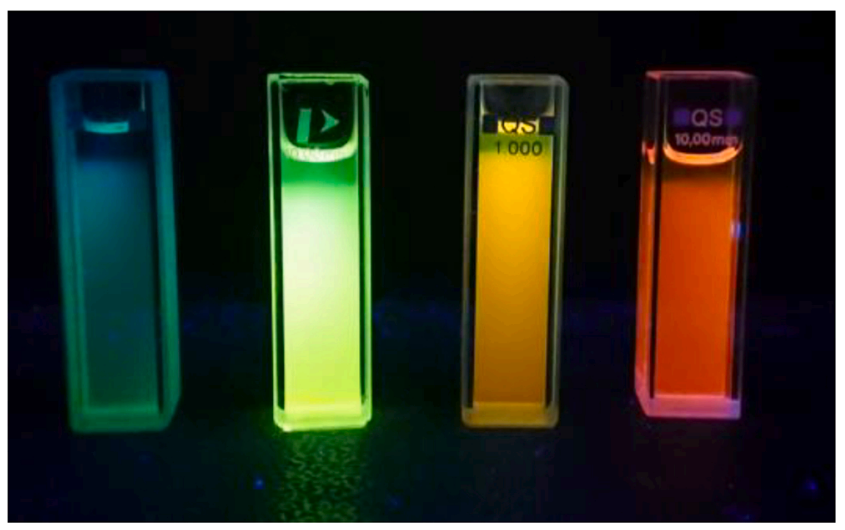

Fig. 3. $n$-heptane solution under UV lamp irradiation (from left to right: $\mathbf{7 b}, \mathbf{8 b}$, 7a, 8a) $c=1-3 \times 10^{-5} \mathrm{M}$. Photographs were taken in the dark upon irradiation with a hand-held lamp $\left(\lambda_{e m}=366 \mathrm{~nm}\right)$.

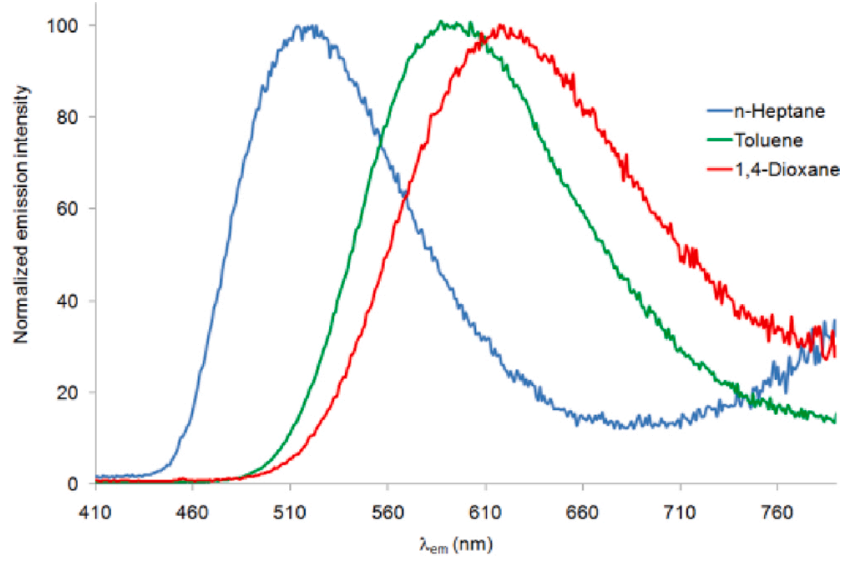

Fig. 4. Normalized emission spectra of $\mathbf{7 b}$ in different aprotic solvents.

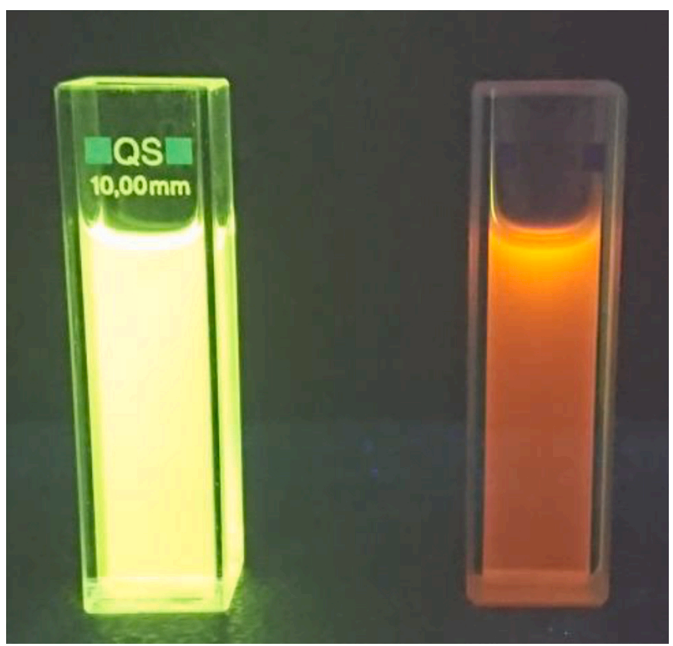

Fig. 5. $n$-Heptane (left) and 1,4-dioxane (right) solution of $\mathbf{8 b}$ under UV lamp $c=3 \times 10^{-5} \mathrm{M}$. Photographs were taken in the dark upon irradiation with a hand-held lamp $\left(\lambda_{e m}=366 \mathrm{~nm}\right)$.

calculated and electrochemical HOMO-LUMO gaps obey the same trends and correlates tightly (Fig. S2) and, therefore we can consider the used DFT method as reliable. In general, the lowest HOMO-LUMO gap has been calculated for chromophores in series a bearing $N, N$-diphenylamino donor. The carbazole-terminated chromophores $\mathbf{b}$ showed
Table 3

Results for EFISH measurements for compounds $\mathbf{7}$ and $\mathbf{8}$.

\begin{tabular}{lllll}
\hline & $\mathbf{7 a}$ & $\mathbf{7 b}$ & $\mathbf{8 a}$ & $\mathbf{8 b}$ \\
\hline$\mu \beta\left(10^{-48} \mathrm{esu}^{\mathrm{a}}\right.$ & 700 & 70 & 1440 & 330 \\
$\mu \beta_{0}\left(10^{-48} \mathrm{esu}\right)^{\mathrm{b}}$ & 485 & 53 & 892 & 237 \\
$\mu \beta / \mathrm{MW}^{\mathrm{c}}$ & 1.91 & 0.19 & 3.88 & 0.89 \\
\hline
\end{tabular}

a $\mu \beta(2 \omega)$ at $1907 \mathrm{~nm}$ in $\mathrm{CHCl}_{3}$. Molecular concentrations used for the measurements were in the range of $10^{-3}$ to $10^{-2} \mathrm{M}, \mu \beta \pm 10 \%$.

b Two level corrected $\mu \beta$ values $\left(\mu \beta_{0}\right)$ [14].

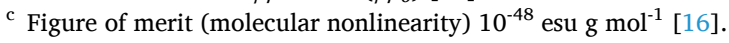

Table 4

DFT-calculated electronic parameters of $\mathbf{7}$ and $\mathbf{8}$.

\begin{tabular}{lllll}
\hline & $\mathbf{7 a}$ & $\mathbf{7 b}$ & $\mathbf{8 a}$ & $\mathbf{8 b}$ \\
\hline$E_{\text {HOMO }}(\mathrm{eV})^{\mathrm{a}}$ & -5.45 & -5.83 & -5.48 & -5.83 \\
$E_{\text {LUMO }}(\mathrm{eV})^{\mathrm{a}}$ & -3.53 & -3.61 & -3.46 & -3.58 \\
$\Delta E(\mathrm{eV})^{\mathrm{a}}$ & 1.92 & 2.22 & 2.02 & 2.25 \\
$\mu(\mathrm{D})^{\mathrm{a}}$ & 10.7 & 6.5 & 13.1 & 8.8 \\
$\lambda_{\max }^{\mathrm{DFT}}(\mathrm{nm} / \mathrm{eV})^{\mathrm{b}}$ & $422(2.94)$ & $367(3.38)$ & $479(2.59)$ & $439(2.82)$ \\
$\beta(-2 \omega, \omega, \omega)\left(10^{-30} \mathrm{esu}\right)^{\mathrm{b}, \mathrm{c}}$ & 215 & 85 & 373 & 149 \\
\hline
\end{tabular}

a Calculated at DFT B3LYP/6-311++G(2df,p) level in $\mathrm{CHCl}_{3}$.

b Calculated at TD-DFT (nstates $=8$ ) CAM-B3LYP/6-311+G(2df,p) level in $\mathrm{CHCl}_{3}$.

c At $1907 \mathrm{~nm}$ in $\mathrm{CHCl}_{3}$.

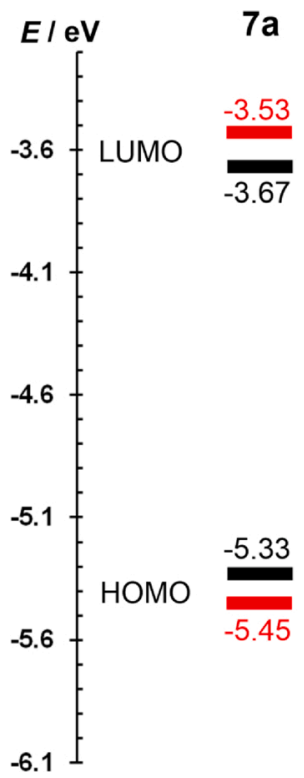

$7 b$

$8 a$

8b

Fig. 6. Energy level diagram showing the electrochemical (black) and calculated (red) HOMO/LUMO energies.

deepened HOMO. The gaps are slightly lower for chromophores 7 with 1,4-phenylene $\pi$-linker.

Fig. 7 shows optimized geometries, HOMO/LUMO localizations and Mulliken charges in target chromophores; see Fig. S3 for complete listing of frontier molecular orbitals. All molecules are unsymmetrical and do not belong to any group of symmetry. Whereas the HOMO is centrally localized either on the diphenylamino or carbazole donors, the LUMO is spread over the adjacent 1,4-phenylene bridge. The Mulliken charges are localized accordingly, involving the donor moieties in $\mathbf{8}$ and mostly the $\pi$-conjugated bridge between the particular donor and acceptor.

The calculated dipole moments reflect the geometry with the out-ofplane orientation of both donor moieties (the torsion angle is about $50^{\circ}$ ). However, molecules in series a bearing more flexible diphenylamino group possess significantly higher ground state dipole moments of 

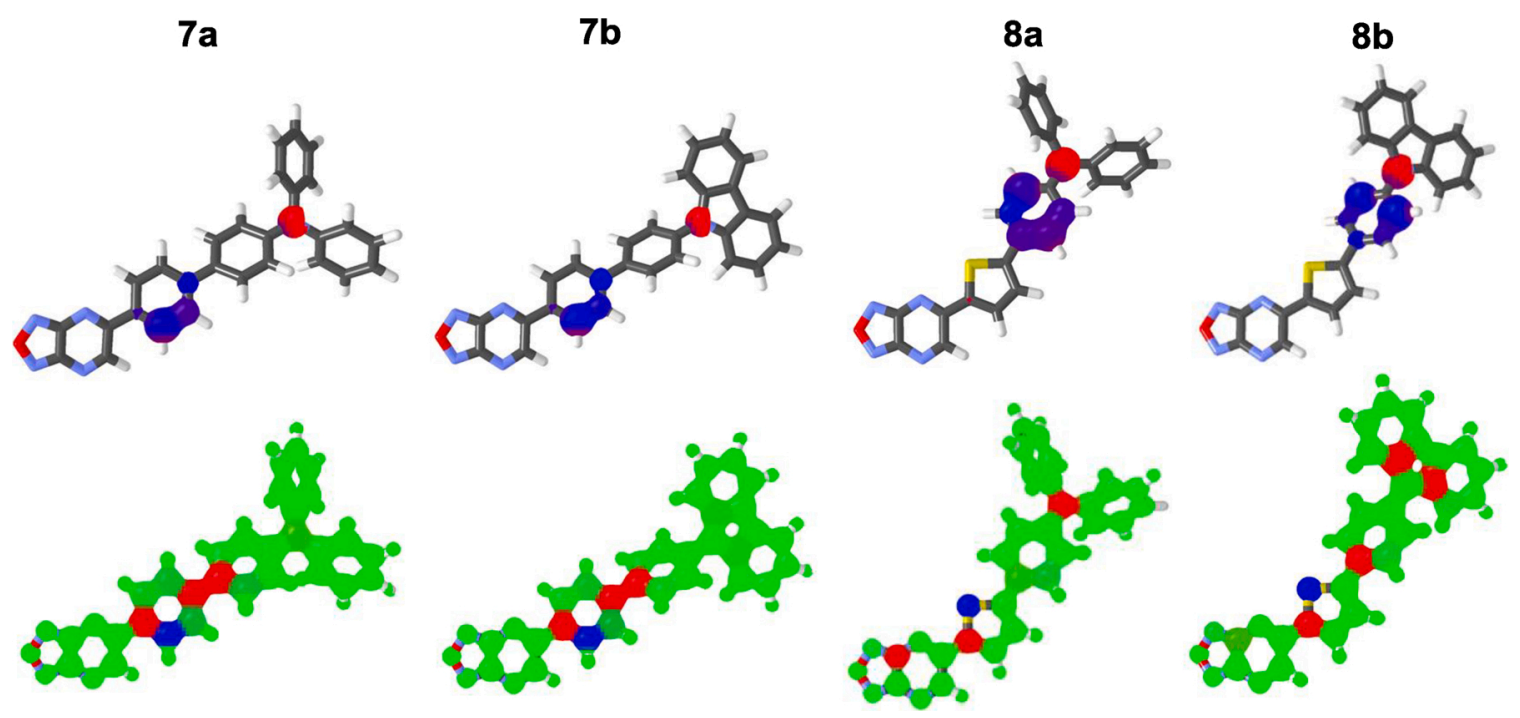

Fig. 7. HOMO (red) and LUMO (blue) localizations (above) and Mulliken charges (below) in chromophores 7a-b and 8a-b.

around 11 and $13 \mathrm{D}$ as compared to carbazole derivatives $\mathbf{b}$ (Table 4).

The fundamental electronic absorption properties were investigated by TD-DFT method; the calculated positions of the longest-wavelength absorption maxima $\lambda_{\max }^{\mathrm{DFT}}$ are gathered in Table 4, the spectra are provided in Fig. S4. The calculated $\lambda_{\max }^{\mathrm{DFT}}$ values correlate tightly with the experimental longest-wavelength absorption maxima measured in dichloromethane (Table 2) - see Fig. S5. The spectra consist of two peaks; the low-energy peak corresponds to the HOMO $\rightarrow$ LUMO transition whereas the high-energy peak involves mostly the HOMO$-2 \rightarrow$ LUMO and HOMO $\rightarrow$ LUMO +1 transitions. When comparing the corresponding pairs of chromophores, chromophores 8a-b bearing 2,5thienylene linker possess bathochromically shifted longest-wavelength absorption maxima. The same trend can be seen for chromophores a with $\mathrm{N}, \mathrm{N}$-diphenylamino donor, when compared to carbazole derivatives $\mathbf{b}$.

First-order hyperpolarizabilities $\beta$ were also calculated as shown in Table 4. The calculated $\beta$ coefficients range from 85 to $373 \times 10^{-30}$ esu. Correlations of the calculated $\beta$ and experimental $\mu \beta$ or $\mu \beta_{0}$ products (EFISH experiment) are provided in Figs. S5 and S6. Both correlations are very tight. In general, larger nonlinearities were calculated for chromophores a with $N, N$-diphenylamino donor, the largest one belongs to chromophore 8a with polarizable 2,5-thienylene $\pi$-linker.

\section{Experimental section}

\subsection{General Information}

All reagents and solvents were obtained from commercial sources and dried by using standard procedures before use. ${ }^{1} \mathrm{H}$ and ${ }^{13} \mathrm{C}$ NMR spectra were recorded on a Bruker AVANCE-500 and AVANCE-600 instruments using $\mathrm{Me}_{4} \mathrm{Si}$ as an internal standard. IR spectra of samples (solid powders) were recorded on a Spectrum One Fourier transform IR spectrometer (Perkin Elmer) equipped with a diffuse reflectance attachment (DRA) in the frequency range $4000 \div 400 \mathrm{~cm}^{-1}$. Spectrum processing and band intensity determination were carried out using the special software supplied with the spectrometer. Elemental analysis was carried on a Eurovector EA 3000 automated analyzer. Melting points were determined on Boetius combined heating stages and were not corrected. The chromatographic purification of compounds was achieved with silica gel Alfa Aesar 0.040-0.063 mm (230-400 mesh), eluting with $\mathrm{CH}_{2} \mathrm{Cl}_{2} /$ hexane $(1: 2, \mathrm{v} / \mathrm{v})$. The progress of reactions and the purity of compounds were checked by TLC on Sorbfil plates (Russia), in which the spots were visualized with UV light ( $\lambda 254$ or $365 \mathrm{~nm}$ ). The electrochemical studies of the compounds were performed with a homedesigned 3-electrodes cell (WE: glassy carbon disk, RE: Ag wire, Ce: Pt). Ferrocene was added at the end of each experiment to determine redox potential values. UV Vis and fluorescence spectra were recorded with a Fluoromax-3 Jobin-Yvon Horiba spectrophotometer using standard $1 \mathrm{~cm}$ quartz cells. Compounds were excited at their absorption maxima (band of lowest energy) to record the emission spectra. The $\Phi_{\mathrm{F}}$ values were calculated using a well-known procedure [18] with 9,10-bis(phenylethenyl)anthracene in cyclohexane $\left(\Phi_{\mathrm{F}}=1.00\right)$ as standard [19]. Experimental details on EFISH measurements are described elsewhere [20].

\subsection{Synthesis of 5-(4-bromophenyl)-[1,2,5]oxadiazolo[3,4-b]pyrazine} (3)

A mixture of 4'-Bromoacetophenone 1 (1.994 g, $10 \mathrm{mmol})$ and selenium dioxide $(1.1 \mathrm{~g}, 10 \mathrm{mmol})$ in a solution of 1,4-dioxane $(15 \mathrm{~mL})$ and water $(1 \mathrm{~mL})$ was refluxed for $12 \mathrm{~h}$. Selenium was filtered off, washed with 1,4-dioxane ( $5 \mathrm{~mL})$. The solvent was evaporated at reduced pressure. The residue was dissolved in a mixture of ethanol $(5 \mathrm{~mL})$ and acetic acid $(5 \mathrm{~mL}), 3$,4-diaminofurazan $(2)(1.0 \mathrm{~g}, 10 \mathrm{mmol})$ was added, and the resulting mixture was refluxed for $1 \mathrm{~h}$ and cooled to room temperature. A precipitate formed was filtered, washed with ethanol, and dried in air. Compound 3 was obtained as a pale yellow solid. Yield $2.023 \mathrm{~g}$ (73\%), mp $159-160{ }^{\circ} \mathrm{C} .{ }^{1} \mathrm{H}$ NMR $\left(500 \mathrm{MHz}, \mathrm{DMSO}-d_{6}\right) \delta 9.80(\mathrm{~s}, 1 \mathrm{H})$, 8.38-8.33 (m, $2 \mathrm{H}), 7.91-7.86(\mathrm{~m}, 2 \mathrm{H}) .{ }^{13} \mathrm{C}$ NMR (126 MHz, DMSO- $\left.d_{6}\right)$

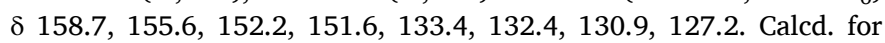
$\mathrm{C}_{10} \mathrm{H}_{5} \mathrm{BrN}_{4} \mathrm{O}$ (277.08): C, 43.35; H, 1.82; N, 20.22. Found: C, 43.37; H, $1.95 ; \mathrm{N}, 20.20$.

\subsection{Synthesis of 5-(5-bromothiophen-2-yl)-[1,2,5]oxadiazolo[3,4-b] pyrazine (5)}

$\mathrm{N}$-Bromosuccinimide ( $4.45 \mathrm{~g}, 25 \mathrm{mmol}$ ) was added to a solution of 5(1-benzothiophen-3-yl)pyrimidine (4) $(2.04 \mathrm{~g}, 10 \mathrm{mmol})$ in DMF $(15 \mathrm{ml})$. The obtained solution was stirred overnight at room temperature. The reaction mixture was diluted with water. The formed precipitate was filtered off, washed with water, dried, and recrystallized from ethanol. Yield $2.406 \mathrm{~g}(85 \%)$, orange solid, mp $213-215^{\circ} \mathrm{C}$. H NMR $\left(500 \mathrm{MHz}, \mathrm{DMSO}-d_{6}\right) \delta 9.73(\mathrm{~s}, 1 \mathrm{H}), 8.40(\mathrm{~d}, J=4.1 \mathrm{~Hz}, 1 \mathrm{H}), 7.58$ (d, $J$ $=4.1 \mathrm{~Hz}, 1 \mathrm{H}) .{ }^{13} \mathrm{C}$ NMR $\left(126 \mathrm{MHz}\right.$, DMSO- $\left.d_{6}\right) \delta 154.5,153.5,152.0$, 151.5, 142.2, 135.4, 133.4, 122.9. Calcd. for $\mathrm{C}_{8} \mathrm{H}_{3} \mathrm{BrN}_{4} \mathrm{OS}$ (283.10): C, 33.94; H, 1.07; N, 19.79. Found: C, 33.90; H, 1.02; N, 19.55 . 
3.4. General procedure for the synthesis of 5-[4-(heteroaryl)phenyl][1,2,5]oxadiazolo[3,4-b]pyrazine $(7 a, b)$ and 5-[5-(heteroaryl)thiophen2-yl]-[1,2,5]oxadiazolo[3,4-b]pyrazine $(8 a, b)$

A mixture of 5-(4-bromophenyl)-[1,2,5] oxadiazolo[3,4-b]pyrazine (3) $(277 \mathrm{mg}, 1.0 \mathrm{mmol}$ ) [or 5-(5-bromothiophen-2-yl)-[1,2,5] oxadiazolo[3,4-b]pyrazine (5) (283 $\mathrm{mg}, 1.0 \mathrm{mmol})$ ], corresponding arylboronic acid 6a,b (1.2 mmol), $\mathrm{Pd}\left(\mathrm{PPh}_{3}\right)_{4}(115 \mathrm{mg}, 10 \mathrm{~mol} \%)$ and $\mathrm{K}_{3} \mathrm{PO}_{3}$ (530 mg, $2.5 \mathrm{mmol}$ ) was dissolved in 1,4-dioxane $15 \mathrm{~mL}$. The reaction mixture was degassed and refluxed for $15 \mathrm{~h}$ under an argon atmosphere. After completion of the reaction (monitored by TLC), the reaction mixture was cooled, filtered, and dissolved in a mixture of EtOAc and water $(1: 1,50 \mathrm{~mL})$, and the organic layer was separated. The aqueous layer was extracted with EtOAc $(2 \times 25 \mathrm{~mL})$. The combined organic extracts were dried with $\mathrm{MgSO}_{4}$ and the solvents evaporated. Purification by silica gel column chromatography with $\mathrm{CH}_{2} \mathrm{Cl}_{2}$ /hexane (1:2, v/ v) as an eluent to afford the title compounds (7 and 8 ).

\section{5. '-([1,2,5]oxadiazolo[3,4-b]pyrazin-5-yl)-N,N-diphenyl-[1,1'- biphenyl]-4-amine (7a)}

Yield $375 \mathrm{mg}$ (85\%), dark violet solid, mp 223-224 ${ }^{\circ} \mathrm{C} .{ }^{1} \mathrm{H}$ NMR (600 MHz, DMSO-d 6 ) $\delta 9.87$ (s, $1 \mathrm{H}), 8.54-8.47$ (m, $2 \mathrm{H}), 7.99-7.94(\mathrm{~m}$, $2 \mathrm{H}), 7.81-7.76(\mathrm{~m}, 2 \mathrm{H}), 7.39-7.35(\mathrm{~m}, 4 \mathrm{H}), 7.14-7.10(\mathrm{~m}, 6 \mathrm{H})$, 7.08-7.05 (m, 2 H). ${ }^{13} \mathrm{C}$ NMR (151 MHz, DMSO- $\left.d_{6}\right) \delta 159.4,156.4$, $152.9,152.1,148.4,147.2,144.3,133.0,132.1,130.2,128.5,127.2$, 125.2, 124.2, 122.9. v (DRA, cm $\left.{ }^{-1}\right) 3062\left(\mathrm{w}, \mathrm{C}-\mathrm{H}_{\mathrm{Ar}}\right), 3053\left(\mathrm{w}, \mathrm{C}-\mathrm{H}_{\mathrm{Ar}}\right)$, $3037\left(\mathrm{w}, \mathrm{C}-\mathrm{H}_{\mathrm{Ar}}\right), 1586\left(\mathrm{~s}, \mathrm{C}-\mathrm{C}_{\mathrm{A}} / \mathrm{C}-\mathrm{N}_{\mathrm{Ar}}\right), 1561\left(\mathrm{~s}, \mathrm{C}-\mathrm{C}_{\mathrm{Ar}} / \mathrm{C}-\mathrm{N}_{\mathrm{Ar}}\right), 1488$ (s, $\mathrm{C}-\mathrm{C}_{\mathrm{Ar}} / \mathrm{C}-\mathrm{N}_{\mathrm{Ar}}$ ), 1446 (s, C- $\left.\mathrm{C}_{\mathrm{Ar}} / \mathrm{C}-\mathrm{N}_{\mathrm{Ar}}\right), 822\left(\mathrm{~s}, \mathrm{C}-\mathrm{H}_{\mathrm{Ar}}\right), 797$ (s, C- $\mathrm{H}_{\mathrm{Ar}}$ ), 753 (s, C- $\mathrm{H}_{\mathrm{Ar}}$ ), 697 (s, C- $\mathrm{H}_{\mathrm{Ar}}$ ). Calcd. for $\mathrm{C}_{28} \mathrm{H}_{19} \mathrm{~N}_{5} \mathrm{O}$ (441.49): C, 76.17; H, 4.34; N, 15.86. Found: C, 75.95; H, 4.32; N, 16.09.

\section{6. -(4'-(9H-Carbazol-9-yl)-[1,1'-biphenyl]-4-yl)-[1,2,5]oxadiazolo $[3,4-b]$ pyrazine $(7 b)$}

Yield $338 \mathrm{mg}(77 \%)$, red solid, mp $288-289^{\circ} \mathrm{C} .{ }^{1} \mathrm{H}$ NMR $(600 \mathrm{MHz}$, DMSO- $\left.d_{6}\right) \delta 9.91(\mathrm{~s}, 1 \mathrm{H}), 8.63-8.57(\mathrm{~m}, 2 \mathrm{H}), 8.28(\mathrm{dt}, J=7.8,1.0 \mathrm{~Hz}$, $2 \mathrm{H}$ ), 8.20-8.11 (m, $4 \mathrm{H}$ ), 7.84-7.78 (m, $2 \mathrm{H}$ ), 7.53-7.45 (m, $4 \mathrm{H}), 7.33$ (ddd, $J=7.9,6.7,1.3 \mathrm{~Hz}, 2 \mathrm{H}) .{ }^{13} \mathrm{C}$ NMR (151 MHz, DMSO-d 6 ) $\delta 159.5$, $156.3,152.9,152.2,143.9,140.5,138.1,137.8,134.0,130.3,129.3$, $128.1,127.7,123.5,121.1,120.8,110.2$. $v\left(\mathrm{DRA}, \mathrm{cm}^{-1}\right) 3034(\mathrm{w}$, C- $\left.\mathrm{H}_{\mathrm{Ar}}\right), 1564$ (s, C- $\left.\mathrm{C}_{\mathrm{Ar}} / \mathrm{C}-\mathrm{N}_{\mathrm{Ar}}\right), 1447$ (s, C- $\left.\mathrm{C}_{\mathrm{Ar}} / \mathrm{C}-\mathrm{N}_{\mathrm{Ar}}\right), 746\left(\mathrm{~s}, \mathrm{C}-\mathrm{H}_{\mathrm{Ar}}\right.$ ), 723 (s, C- $\mathrm{H}_{\text {Ar }}$ ). Calcd. for $\mathrm{C}_{28} \mathrm{H}_{17} \mathrm{~N}_{5} \mathrm{O}$ (439.48): C, 76.52; $\mathrm{H}, 3.90 ; \mathrm{N}$, 15.94. Found: C, 76.65; H, 3.78; N, 16.10 .

\section{7. -(5-([1,2,5]oxadiazolo[3,4-b]pyrazin-5-yl)thiophen-2-yl)- $N, N$ - diphenylaniline (8a)}

Yield $349 \mathrm{mg}(78 \%)$, violet solid, $\mathrm{mp} 248-249^{\circ} \mathrm{C} .{ }^{1} \mathrm{H}$ NMR $(600 \mathrm{MHz}$, DMSO- $\left.d_{6}\right) \delta 9.74(\mathrm{~s}, 1 \mathrm{H}), 8.55(\mathrm{~d}, J=4.2 \mathrm{~Hz}, 1 \mathrm{H}), 7.81-7.74(\mathrm{~m}, 2 \mathrm{H})$, $7.72(\mathrm{~d}, J=4.2 \mathrm{~Hz}, 1 \mathrm{H}), 7.42-7.33(\mathrm{~m}, 4 \mathrm{H}), 7.20-7.07(\mathrm{~m}, 6 \mathrm{H})$, $7.01-6.95(\mathrm{~m}, 2 \mathrm{H}) .{ }^{13} \mathrm{C}$ NMR $\left(151 \mathrm{MHz}, \mathrm{DMSO}-d_{6}\right) \delta 155.5,154.5$, 153.7, 152.8, 152.0, 149.2, 146.8, 139.0, 137.0, 130.3, 127.9, 125.9, 125.6, 125.5, 124.7, 121.9. v (DRA, $\left.\mathrm{cm}^{-1}\right) 3085\left(\mathrm{w}, \mathrm{C}-\mathrm{H}_{\mathrm{Ar}}\right), 3062(\mathrm{w}$, C- $\left.\mathrm{H}_{\mathrm{Ar}}\right), 3035$ (w, C- $\mathrm{H}_{\mathrm{Ar}}$ ), 1589 (s, C-C $\left.\mathrm{C}_{\mathrm{Ar}} / \mathrm{C}-\mathrm{N}_{\mathrm{Ar}}\right), 1568$ (s, C- $\mathrm{C}_{\mathrm{Ar}} /$ $\left.\mathrm{C}-\mathrm{N}_{\mathrm{Ar}}\right), 1488$ (s, C- $\mathrm{C}_{\mathrm{Ar}} / \mathrm{C}-\mathrm{N}_{\mathrm{Ar}}$ ), $1438\left(\mathrm{~s}, \mathrm{C}-\mathrm{C}_{\mathrm{Ar}} / \mathrm{C}-\mathrm{N}_{\mathrm{Ar}}\right), 1405$ (s, C- $\mathrm{C}_{\mathrm{Ar}} /$ $\left.\mathrm{C}-\mathrm{N}_{\mathrm{Ar}}\right), 833\left(\mathrm{~s}, \mathrm{C}-\mathrm{H}_{\mathrm{Ar}}\right), 751$ (s, C- $\left.\mathrm{H}_{\mathrm{Ar}}\right), 694$ (s, C- $\mathrm{H}_{\mathrm{Ar}}$ ). Calcd. for $\mathrm{C}_{26} \mathrm{H}_{17} \mathrm{~N}_{5} \mathrm{OS}$ (447.52): C, 69.78; H, 3.83; N, 15.65. Found: C, 69.83; H, $3.77 ; \mathrm{N}, 15.67$.

\section{8. -(5-(4-(9H-Carbazol-9-yl)phenyl)thiophen-2-yl)-[1,2,5]oxadiazolo [3,4-b]pyrazine $(8 b)$}

Yield $321 \mathrm{mg}$ (72\%), red solid, mp $246-248{ }^{\circ} \mathrm{C} .{ }^{1} \mathrm{H}$ NMR $(600 \mathrm{MHz}$, DMSO-d $\left.d_{6}\right) \delta 9.82$ (d, $\left.J=2.1 \mathrm{~Hz}, 1 \mathrm{H}\right), 8.66$ (dd, $\left.J=4.0,2.2 \mathrm{~Hz}, 1 \mathrm{H}\right), 8.28$ (dt, $J=7.8,1.1 \mathrm{~Hz}, 2 \mathrm{H}$ ), $8.21-8.15(\mathrm{~m}, 2 \mathrm{H}), 8.00$ (dd, $J=4.0,2.2 \mathrm{~Hz}$,
$1 \mathrm{H}), 7.83-7.78$ (m, $2 \mathrm{H}$ ), $7.54-7.44$ (m, $4 \mathrm{H}$ ), 7.33 (ddd, $J=7.9,6.9$, $1.2 \mathrm{~Hz}, 2 \mathrm{H}) .{ }^{13} \mathrm{C}$ NMR $\left(151 \mathrm{MHz}\right.$, DMSO-d $\left.d_{6}\right) \delta 155.4,154.7,152.7$, $152.2,152.1,140.5,140.3,138.4,136.8,131.8,128.4,127.8,127.3$, 126.9, 123.5, 121.1, 120.9, 110.3. v (DRA, cm ${ }^{-1}$ ) 3093 (br. w, C- $\mathrm{H}_{\mathrm{Ar}}$ ), 3080 (br. w, C- $\mathrm{H}_{\mathrm{Ar}}$ ), 3060 (br. w, C- $\mathrm{H}_{\mathrm{Ar}}$ ), 3028 (br. w, C- $\mathrm{H}_{\mathrm{Ar}}$ ), 1599 (s, C- $\mathrm{C}_{\mathrm{Ar}} / \mathrm{C}-\mathrm{N}_{\mathrm{Ar}}$ ), 1567 (s, C- $\mathrm{C}_{\mathrm{Ar}} / \mathrm{C}-\mathrm{N}_{\mathrm{Ar}}$ ), 1533 (s, C- $\mathrm{C}_{\mathrm{Ar}} / \mathrm{C}-\mathrm{N}_{\mathrm{Ar}}$ ), 1449 (s, C- $\left.\mathrm{C}_{\mathrm{Ar}} / \mathrm{C}-\mathrm{N}_{\mathrm{Ar}}\right), 1406$ (s, C- $\left.\mathrm{C}_{\mathrm{Ar}} / \mathrm{C}-\mathrm{N}_{\mathrm{Ar}}\right), 837$ (s, C- $\left.\mathrm{H}_{\mathrm{Ar}}\right), 749\left(\mathrm{~s}, \mathrm{C}-\mathrm{H}_{\mathrm{Ar}}\right)$, 724 (s, C- $\mathrm{H}_{\mathrm{Ar}}$ ). Calcd. for $\mathrm{C}_{26} \mathrm{H}_{15} \mathrm{~N}_{5} \mathrm{OS}$ (445.50): C, 70.10; H, 3.39; N, 15.72. Found: C, 70.00; H, 3.54; N, 15.56 .

\section{Conclusion}

In summary, four new push-pull chromophores bearing $[1,2,5]$ oxadiazolo[3,4-b]pyrazine as electron-withdrawing part and amino group as donor were designed. There electrochemical and photophysical properties indicate that intense ICT occurs in these structures with electrochemical gap below $2.1 \mathrm{eV}$ and strong emission solvatochromism. NLO responses were also measured by EFISH method. All experimental and theoretical results indicate a significant increase of ICT when the diphenylamino electro-donating group is used and when a 2,5-thienylene bridge is replacing the 1,4-phenylene linker. Compound $8 \mathrm{a}$, that combines these two characteristics, exhibits a particularly high figure of merit and appears as an interesting candidate for incorporation in a polymeric matrix to obtain a material with the high electro-optic coefficient.

\section{Declaration of Competing Interest}

The authors report no declarations of interest.

\section{Acknowledgments}

VEV is grateful to the financial support for the synthetic part from the Russian Foundation for Basic Research (Research Project No. 18-29$23045 \mathrm{mk})$.

\section{Appendix A. Supplementary data}

Supplementary material related to this article can be found, in the online version, at doi:https://doi.org/10.1016/j.jphotochem.2020. 112900 .

\section{References}

[1] (a) R. Dorn, D. Baumns, P. Kersten, R. Regener, Nonlinear optical materials for integrated optics: Telecommunications and sensors, Adv. Mater. 4 (1992) 460-473; (b) S.R. Marder, J.W. Perry, Molecular materials for second-order nonlinear optical applications, Adv. Mater. 5 (1993) 804-815;

(c) J. Zyss, Molecular nonlinear optics: Materials, physics and devices, Academic Press, New York, 1994;

(d) C. Ye, J. Zyss, Theory and Practice of Nonlinear Optical Molecules, Chemical Industrial Publishing House, Beijing, 1996;

(e) M.B. Ros, Organic Materials for Nonlinear Optics, in: J.J. Novoa, D. Braga, L. Addadi (Eds.), Engineering of Crystalline Materials Properties. NATO Science for Peace and Security Series B: Physics and Biophysics, Springer, Dordrecht, 2008; (f) D. Dini, M.J.F. Calvete, M. Hanack, Nonlinear Optical Materials for the Smart Filtering of Optical Radiation, Chem. Rev. 116 (2016) 13043-13233; (g) J. Liu, C. Ouyang, F. Huo, W. He, A. Cao, Progress in the enhancement of electro-optic coefficients and orientation stability for organic second-order nonlinear optical materials, Dyes Pigm. 181 (2020), 108509.

[2] F. Bureš, Fundamental aspects of property tuning in push-pull molecules, RSC Adv. 4 (2014) 58826-58851.

[3] (a) S. Achelle, C. Baudequin, N. Plé, Luminescent materials incorporating pyrazine or quinoxaline moieties, Dyes Pigm. 98 (2013) 575-600; (b) P. Meti, H.-H. Park, Y.-D. Gong, Recent developments in pyrazine functionalized pi-conjugated materials for optoelectronic applications, J. Mater. Chem. C 8 (2020) 352-379.

[4] (a) P. Wang, P. Zhu, W. Wu, H. Kang, C. Ye, Design of novel nonlinear optical chromophores with multiple substitutions, Phys. Chem. Chem. Phys. 1 (1999) 3519-3525; (b) N. Hebbar, Y. Ramondenc, G. Plé, G. Dupas, N. Plé, Push-pull structures with a pyrazine core and hexatriene chain: synthesis and light-emitting properties, 
Tetrahedron 65 (2009) 4190-4200;

(c) F. Bureš, H. Čermáková, J. Kulhánek, M. Ludwig, W. Kuznik, I.V. Kityk, T. Mikysek, A. Růžička, Structure-Property Relationships and Nonlinear Optical Effects in Donor-Substituted Dicyanopyrazine-Derived Push-Pull Chromophores with Enlarged and Varied $\pi$-Linkers, Eur. J. Org. Chem. (2012) 529-538; (d) S. Gauthier, N. Vologdin, S. Achelle, A. Barsella, B. Caro, F. Robin-le Guen, Methylenepyran based dipolar and quadrupolar dyes: synthesis, electrochemical and photochemical properties, Tetrahedron 69 (2013) 8392-8399;

(e) B.J. Coe, J. Fielden, S.P. Foxon, I. Asselberghs, K. Clays, B.S. Brunschwig, TwoDimensional, Pyrazine-Based Nonlinear Optical Chromophores with Ruthenium(II) Amine Electron Donors, Inorg. Chem. 49 (2010) 10718-10726;

(f) L. Dokládalová, F. Bureš, W. Kuznik, I.V. Kityk, A. Wojciechowski, T. Mikysek, N. Almonasy, M. Ramaiyan, Z. Padělková, J. Kulháneka, M. Ludwig,

Dicyanobenzene and dicyanopyrazine derived X-shaped charge-transfer chromophores:comparative and structure-property relationship study, Org. Biomol. Chem. 12 (2014) 5517-5527;

(g) S. Achelle, A. Barsella, C. Baudequin, B. Caro, F. Robin-le Guen, Synthesis and photophysical investigation of a series of push-pull arylvinyldiazine chromophores, J. Org. Chem. 77 (2012) 4087-4096;

(h) F. Castet, A. Pic, B. Champagne, Linear and nonlinear optical properties of arylvinyldiazine dyes: a theoretical investigation, Dyes Pigm. 110 (2014) 256-260; (i) S. Achelle, S. Kahlal, J.-Y. Saillard, N. Cabon, B. Caro, F. Robin-le Guen, Dipolar and V-shaped structures incorporating methylenepyran and diazine fragments, Tetrahedron 70 (2014) 2804-2815.

[5] (a) M. Rumi, S.J.K. Pond, T. Meyer-Friedrichen, Q. Zhang, M. Bishop, Y. Zhang, S. Barlow, S.R. Marder, J.W. Perry, Tetrastyrylarene Derivatives: Comparison of One- and Two-Photon Spectroscopic Properties with Distyrylarene Analogues, J. Phys. Chem. C 112 (2008) 8061-8071;

(b) Y. Sun, X.-T. Liu, J.-F. Guo, A.-M. Ren, D. Wang, Theoretical investigation of two-photon absorption and fluorescence properties of cypridina luciferin-based derivatives: 2,3,5-trisubstituted pyrazine compounds, J. Phys. Org. Chem. 26 (2013) 822-833;

(c) M. Chen, H. Nie, B. Song, L. Li, J.Z. Sun, A. Qin, B.Z. Tang, Triphenylaminefunctionalized tetraphenylpyrazine: facile preparation and multifaceted functionalities, J. Mater. Chem. C 4 (2016) 2901-2908;

(d) H. Li, Y. Zhang, Z. Bi, R. Xu, M. Li, X. Shen, G. Tang, K. Han, Theoretical study on the spectroscopic and third-order nonlinear optical properties of twodimensional charge-transfer pyrazine derivatives, Mol. Phys. 115 (2017) 3164-3171;

(e) T.-C. Lin, B.-K. Tsai, T.-Y. Huang, W. Chien, Y.-Y. Liu, M.-H. Li, M.-Y. Tsai, Synthesis and two-photon absorption properties of truxene-cored chromophores with functionalized pyrazine units fused as the end-groups, Dyes Pigm. 120 (2015) 98-111;

(f) T.-C. Lin, B.-K. Tsai, Y.-Y. Liu, M.-Y. Tsai, Synthesis and two-photon absorption properties of ladder-type chromophores with functionalized pyrazine units fused as the end-groups, Eur. J. Org. Chem. (2014) 6163-6174.

[6] A.B. Sheremetev, I.L. Yudin, Advances in the chemistry of furazano[3,4-b] pyrazines and their analogues, Russ. Chem. Rev. 72 (2003) 87-99.

[7] (a) Y.A. Kvashnin, N.A. Kazin, E.V. Verbitskiy, T.S. Svalova, A.V. Ivanova, A. N. Kozitsina, P.A. Slepukhin, G.L. Rusinov, O.N. Chupakhin, V.N. Charushin, A facile, metal-free, oxidative coupling of new 6-(hetero)aryl-[1,2,5] oxadiazolo $[3,4-b]$ pyrazines with pyrroles, indoles and carbazoles, ARKIVOC 279-300 (2016); (b) E.V. Verbitskiy, Y.A. Kvashnin, A.A. Baranova, Y.A. Yakovleva, K.O. Khokhlov, G.L. Rusinov, V.N. Charushin, 9-Ethyl-3-\{6-(het)aryl-[1,2,5]oxadiazolo[3,4-b] pyrazin-5-yl\}-9H-carbazoles: synthesis and study of sensitivity to nitroaromatic compounds, Russ. Chem. Bull. 67 (2018) 1078-1082.

[8] (a) R. Lartia, C. Allain, G. Bordeau, F. Schmidt, C. Fiorini-Debuisschert, F. Charra, M.-P. Teulade-Fichou, Synthetic strategies to derivatizable triphenylamines displaying high two-photon absorption, J. Org. Chem. 73 (2008) 1732-1744; (b) H. Detert, V. Schmidt, Quadrupolar donor-acceptor substituted oligo (phenylenevinylene)s-synthesis ans solvatochromsim of the fluorescence, J. Phys. Org. Chem. 17 (2004) 1051-1056.

[9] (a) J. Kulhanek, F. Bureš, J. Opšal, W. Kuznik, T. Mikysek, A. Růžičcka, 1,4Phenylene and 2,5-thienylene $\pi$-linkers in charge-transfer chromophores, Asian J. Org. Chem. 2 (2013) 422-431;

(b) M. Klikar, P. le Poul, A. Růžička, O. Pytela, A. Barsella, K.D. Dorkenoo, F. Robin-le Guen, F. Bureš, S. Achelle, Dipolar NLO chromophores bearing diazine rings as $\pi$-conjugated linkers, J. Org. Chem. 82 (2017) 9435-9451.
[10] (a) E.V. Verbitskiy, A.A. Baranova, K.I. Lugovik, K.O. Khokhlov, E.M. Cheprakova, G.L. Rosinov, O.N. Chupakhin, V.N. Charunshin, New V-shaped push-pull systems based on 4,5-di(hetero)aryl substituted pyrimidines: their synthesis and application to the detection of nitroaromatic explosives, ARKIVOC iii (2016) 360-373;

(b) E.V. Verbitskiy, A.A. Baranova, K.I. Lugovik, K.O. Khokhlov, E.M. Cheprakova, M.Z. Shafikov, G.L. Rusinov, O.N. Chupakhin, V.N. Charushin, New 4,5-di(hetero) arylpyrimidines as sensing elements for detection of nitroaromatic explosives in vapor phase, Dyes Pigm. 137 (2017) 360-371.

[11] (a) C. Katan, M. Charlot, O. Mongin, C. Le Droumaguet, V. Jouikov, F. Terenziani, E. Badaeva, S. Tretiak, M. Blanchard-Desce, Simultaneous control of emission localization and two-photon absorption efficiency in dissymmetrical chromophores, J. Phys. Chem. B 114 (2010) 3152-3169; (b) F.K. Merkt, S.P. Höwedes, C.F. Gers-Panther, I. Gruber, C. Janiak, T.J. J. Müller, Three-component activation/alkynylation/cyclocondensation (AACC) synthesis of enhanced emission solvatochromic 3-ethynylquinoxalines, Chem.-Eur J. 24 (2018) 8114-8125;

(c) J. Rodríguez-Aguilar, M. Vidal, C. Pastenes, C. Aliaga, M.C. Rezende, M. Domínguez, The solvatofluorochromism of 2,4,6-triarylpyrimidine derivatives, Photochem. Photobiol. 94 (2018) 1100-1108.

[12] (a) S. Achelle, F. Robin-le Guen, Emission properties of diazines chromophores: structure-properties relationship, J. Photochem. Photobiol A Chem. 348 (2017) 281-286;

(b) M. Fecková, P. le Poul, F. Robin-le Guen, T. Roisnel, O. Pytela, M. Klikar, F. Bureš, S. Achelle, 2,4-distyryl- and 2,4,6-tristyrylpyrimidines: synthesis and photophysical properties, J. Org. Chem. 83 (2018) 11712-11726.

[13] K. Hoffert, R.J. Durand, S. Gauthier, F. Robin-le Guen, S. Achelle, Synthesis and photophysical properties of a series of pyrazine-based push-pull chromophores, Eur. J. Org. Chem. (2017) 523-529.

[14] (a) K.D. Singer, A.F. Garito, Measurements of molecular second order optical susceptibilities using dc induced second harmonic generation, J. Chem. Phys. 75 (1981) 3572;

(b) B.F. Levine, C.G. Bethea, Molecular hyperpolarizabilities determined from conjugated and nonconjugated organic liquids, Appl. Phys. Lett. 24 (1974) 445; (c) I. Ledoux, J. Zyss, Influence of the molecular environment in solution measurements of the second order optical susceptibility for urea and derivatives, Chem. Phys. 73 (1982) 203-213.

[15] (a) J.L. Oudar, D.S. Chemla, Hyperpolarizabilities of the nitroanilines and their relations to the excited state dipole moment, J. Chem. Phys. 66 (1977) 2664-2668; (b) D.R. Kanis, M.A. Ratner, T.J. Marks, Design and construction of molecular assemblies with large second order optical nonlinearities. Quantum chemical aspects, Chem. Rev. 94 (1994) 195-242.

[16] M. Rutkis, A. Jurgis, V. Kampars, A. Vembris, A. Tokmakovs, V. Kokars, New Figure of Merit for Tailoring Optimal Structure of the Second Order NLO Chromophore for Guest-Host Polymers, Mol. Cryst. Liquid Cryst. 485 (2008) 903-914.

[17] M.J. Frisch, G.W. Trucks, H.B. Schlegel, G.E. Scuseria, M.A. Robb, J.R. Cheeseman, G. Scalmani, V. Barone, G.A. Petersson, H. Nakatsuji, X. Li, M. Caricato, A. V. Marenich, J. Bloino, B.G. Janesko, R. Gomperts, B. Mennucci, H.P. Hratchian, J. V. Ortiz, A.F. Izmaylov, J.L. Sonnenberg, D. Williams-Young, F. Ding, F. Lipparini, F. Egidi, J. Goings, B. Peng, A. Petrone, T. Henderson, D. Ranasinghe, V. G. Zakrzewski, J. Gao, N. Rega, G. Zheng, W. Liang, M. Hada, M. Ehara, K. Toyota, R. Fukuda, J. Hasegawa, M. Ishida, T. Nakajima, Y. Honda, O. Kitao, H. Nakai, T. Vreven, K. Throssell, J.A. Montgomery Jr., J.E. Peralta, F. Ogliaro, M. J. Bearpark, J.J. Heyd, E.N. Brothers, K.N. Kudin, V.N. Staroverov, T.A. Keith, R. Kobayashi, J. Normand, K. Raghavachari, A.P. Rendell, J.C. Burant, S.S. Iyengar, J. Tomasi, M. Cossi, J.M. Millam, M. Klene, C. Adamo, R. Cammi, J.W. Ochterski, R.L. Martin, K. Morokuma, O. Farkas, J.B. Foresman, D.J. Fox, Revision A.03.03, Gaussian 16., 2016.

[18] D.F. Eaton, References materials for fluorescence measurement, Pure Appl. Chem. 60 (1988) 1107-1114.

[19] M. Taniguchi, J.S. Lindsey, Database of absorption and fluorescence spectra of $\& 300$ common compounds for use in PhotochemCAD, Photochem. Photobiol. 94 (2018) 290-327.

[20] G. Ulrich, A. Barsella, A. Boeglin, S. Niu, R. Ziessel, BODIPY-bridged push-pull chromophores for nonlinear applications, ChemPhysChem 15 (2014) 2693-2700. 